\title{
LOCALIZATION OF RESPIRATORY ENZYMES IN ESCHERICHIA COLI GROWN WITH OR WITHOUT OXYGEN AND GLUCOSE
}

\author{
KOHJI SHIGETA AND SEIICHI HINO \\ Botanical Institute, Faculty of Science, Hiroshima University, \\ Hiroshima 730, Japan
}

(Received January 13, 1975)

\begin{abstract}
The activities of enzymes in the Krebs cycle and in electron transport were determined with membrane and soluble fractions of Escherichia coli cells grown aerobically or anaerobically with or without glucose. The absence of oxygen during growth decreased the levels of aconitate hydratase, isocitrate lyase, isocitrate dehydrogenase, fumarate hydratase, NADP-malate dehydrogenase, NADH-oxidase, and cytochrome $b_{1}$, while the presence of glucose repressed the levels of aconitate hydratase, isocitrate lyase, fumarate hydratase, and succinate dehydrogenase. Formate dehydrogenase was repressed only when cells were grown anaerobically with glucose, while NADPH-oxidase and menadione reductase were neither repressed by glucose nor by anaerobiosis. Regardless of the cultural conditions, most of the activities of formate dehydrogenase, succinate dehydrogenase, $\mathrm{NADH}$ oxidase, and cytochrome $b_{1}$ were found in the membrane fraction, but the proportions of the activities found in soluble fraction considerably increased when the formation of these enzymes was repressed by anaerobiosis or by glucose.
\end{abstract}

The content of enzymes in electron transport and in the Krebs cycle is markedly diminished when yeast cells are grown under conditions where oxygen is not available (1). The formation of these enzymes is also repressed when yeast cells are grown in the presence of glucose (2). Concomitant with the decrease in the content of respiratory enzymes, distinct defect in mitochondrial structure is revealed in yeast cells that are grown anaerobically or grown with glucose $(2,3)$.

A similar repression of the formation of enzymes in electron transport and in the Krebs cycle by anaerobiosis or by glucose has been reported with Escherichia coli (4-6). In contrast with yeast, E. coli does not contain mitochondria, and only cytoplasmic membraneous structure in the bacterium is the plasma membrane. It has been reported that some of the respiratory enzymes in E. coli are 
primarily membrane-bound, while others are predominantly soluble $(5,7)$. It is the purpose of this study to examine whether there is any change in the structural distribution of respiratory enzymes in $E$. coli when the formation of these enzymes is repressed by anaerobiosis or by glucose.

\section{MATERIALS AND METHODS}

Organisms and cultural conditions. The bacteria and growth media were the same as used in our previous studies $(6,8)$. Escherichia coli K12 W1895 was grown in a nutrient broth containing peptone and meat extract, with or without further addition of $1 \%$ glucose. For aerobic cultures, $0.1 \%$ inoculum was added to $200 \mathrm{ml}$ of the broth in a $500-\mathrm{ml}$ culture flask which was shaken on a reciprocating shaker at 120 strokes $/ \mathrm{min}$ with an amplitude of $6 \mathrm{~cm}$. For anaerobic cultures, $0.1 \%$ inoculum was added to the broth which was filled to the narrow neck of a 2,500-ml culture flask; after inoculation, cotton plug was pushed down, a small beaker containing alkaline pyrogallol was placed on the plug, and the flask was sealed with a rubber stopper and incubated without shaking.

Preparation of soluble and membrane fractions. After incubation for $18 \mathrm{hr}$ at $30^{\circ}$, cells were harvested and washed three times by centrifugation with $0.02 \mathrm{M}$, $\mathrm{pH} 7.2$ phosphate buffer. The procedure to obtain membrane and soluble fractions was a modification of the method described by Nagata et al. (9). One gram of wet cells was suspended in $60 \mathrm{ml}$ of the incubation mixture containing $100 \mu \mathrm{g} / \mathrm{ml}$ lysozyme, $400 \mu \mathrm{g} / \mathrm{ml}$ EDTA, and $0.6 \mathrm{M}$ sucrose. After incubation for $15 \mathrm{~min}$ at $30^{\circ}$, most cells were converted to spheroplasts, which were recovered by centrifugation at $15,000 \times g$ for $20 \mathrm{~min}$. Spheroplasts were suspended in $16 \mathrm{ml}$ of "lysis buffer" containing $10 \mu \mathrm{g} / \mathrm{ml}$ deoxyribonuclease I, $0.005 \mathrm{M} \mathrm{MgCl}_{2}$, and $0.05 \mathrm{M}$ Tris buffer ( $\mathrm{pH}$ 7.6), and homogenized by a Potter-Elvehjem glass homogenizer. The ruptured cell suspension was centrifuged at $15,000 \times g$ for $20 \mathrm{~min}$ and the supernatant (supernatant 1) was saved. The precipitated spheroplast membranes were resuspended in $4 \mathrm{ml}$ of the lysis buffer and centrifuged at $15,000 \times g$ for $20 \mathrm{~min}$. The supernatant (supernatant 2) was saved and the precipitate was suspended in $10 \mathrm{ml}$ of $0.05 \mathrm{M}$ Tris buffer containing $0.005 \mathrm{M} \mathrm{MgCl}_{2}$, and centrifuged at $15,000 \times g$ for $20 \mathrm{~min}$. The precipitate was suspended in $0.05 \mathrm{M}$ Tris buffer containing $0.005 \mathrm{M} \mathrm{MgCl}_{2}$ in an appropriate dilution and used as the membrane fraction. The supernatant from the last centrifugation was combined with supernatants 1 and 2, and used as the soluble fraction.

Assay of acetate oxidation and enzyme activities. Acetate oxidation was followed by the conventional manometric method at $30^{\circ}$. To each Warburg flask were added $1 \mathrm{ml}$ of $0.1 \mathrm{M}, \mathrm{pH} 7.2$ phosphate buffer, $0.5 \mathrm{ml}$ of $0.1 \mathrm{M}$ sodium acetate, and cell fractions in a total volume of $3.0 \mathrm{ml}$. The activity of acetate oxidation was expressed as $\mu \mathrm{l}$ of oxygen taken up per $\mathrm{mgN}$ of the cell fractions. The amount of nitrogen was determined by a Kjeldahl method. 
The assay procedures for the measurement of enzymes, with the exception of menadione reductase, are those described by TAKAHASHI and Hino (6) and are briefly summarized here. Aconitate hydratase (citrate(isocitrate) hydro-lyase, EC 4.2.1.3) and fumarate hydratase (L-malate hydro-lyase, EC 4.2.1.2) were assayed by the formation of aconitate or fumarate from isocitrate or malate, respectively, at $240 \mathrm{~nm}$; isocitrate lyase $\left(\mathrm{L}_{\mathrm{s}}\right.$-isocitrate glyoxylate-lyase, EC 4.1.3.1) was assayed by the formation of glyoxylate phenylhydrazone from isocitrate and phenylhydrazine at $324 \mathrm{~nm}$; isocitrate dehydrogenase $\left(\mathrm{L}_{\mathrm{s}}\right.$-isocitrate: NADP oxidoreductase (decarboxylating), EC 1.1.1.42) and malate dehydrogenase (decarboxylating) (Lmalate: NADP oxidoreductase, EC 1.1.1.40) were determined by the reduction of NADP by isocitrate or malate at $340 \mathrm{~nm}$; malate dehydrogenase (L-malate: NAD oxidoreductase, EC 1.1.1.37) was assayed by the oxidation of NADH by oxaloacetate in the presence of cyanide at $340 \mathrm{~nm}$; formate dehydrogenase (formate: cytochrome $b_{1}$ oxidoreductase, EC 1.2.2.1) was assayed by the reduction of 2,6dichlorophenol-indophenol by formate at $600 \mathrm{~nm}$; succinate dehydrogenase (succinate: (acceptor) oxidoreductase, EC 1.3.99.1) was assayed by the reduction of the same dye by succinate as mediated by phenazine methosulfate; and NADH oxidase system and NADPH oxidase system were assayed by oxidation of NADH or NADPH by air at $340 \mathrm{~nm}$. The reaction mixture for the measurement of menadione reductase (NADH: 2-methyl-1,4-naphthoquinone oxidoreductase, EC 1.6.5.2) contained $0.1 \mathrm{~mm} \mathrm{NADH}, 0.16 \mathrm{~mm}$ menadione, and $1.0 \mathrm{mM} \mathrm{KCN}$ in $3 \mathrm{ml}$ of $0.05 \mathrm{M}, \mathrm{pH} 8.0$ Tris-sulfate buffer, and the reaction was followed by the decrease of absorbancy at $340 \mathrm{~nm}(10)$. The distribution pattern of all enzymes between soluble and membrane fractions was determined by measuring the enzyme activities in these two fractions, expressed as $\mu \mathrm{mol}$ of substrate consumed or product formed per min per total membrane or soluble fraction obtained from $100 \mathrm{mg}$ (wet weight) unbroken cells.

Spectrophotometric measurements. In all enzyme assays, the changes in absorbancy were followed with a Shimadzu recording spectrophotometer Model MPS-50. The cytochrome spectra of soluble and membrane fractions were measured with the spectrophotometer after cytochromes were reduced with dithionite. The concentration of cytochrome $b_{1}$, the predominant cytochrome in $E$. coli, was measured by the peak height at $428 \mathrm{~nm}$ ( $\gamma$ peak) above the line connecting the points at $390 \mathrm{~nm}$ and $450 \mathrm{~nm}$ on the absorption curve. The content of the cytochrome was expressed by absorbancy of the solution which contained soluble or membrane fraction from the original $100 \mathrm{mg}$ cells per $\mathrm{ml}$.

Chemicals. Deoxyribonuclease I, egg white lysozyme, NADH, NADP, and phenazine methosulfate were purchased from Sigma; NADPH was from Boehringer und Soehne; 2,6-dichlorophenol-indophenol was from Wako Chemical; menadione was from Katayama Chemical; and DL-isocitrate (trisodium salt) was from Nutritional Biochemical Co. 


\section{RESULTS AND DISCUSSION}

In the present experiment, spheroplasts were prepared by incubation of the cells with lysozyme in $0.6 \mathrm{~m}$ sucrose solution and were collected by centrifugation. If the spheroplast fraction contained some cells that remained intact after the lysozyme treatment, these cells must have resisted osmotic rupture and mixed into the membrane fraction. The absence of such intact cells in the membrane fraction was confirmed by microscopic observation and by the measurement of acetate oxidation, since intact cells are able, but cell-free extracts are unable, to oxidize acetate (11). As shown in Fig. 1, little oxygen was taken up by the membrane fraction. This result confirms that intact cells were negligible in the membrane fraction.

Tables 1 lists the activities of enzymes in the Krebs cycle and in electron transport, which were localized in the soluble or membrane fraction from the cells grown aerobically without glucose, aerobically with glucose, anaerobically without glucose, and anaerobically with glucose. Table 2 summarizes the effect of environmental growth conditions on the level of the total activity (sum of the activity in the soluble and membrane fraction) and percentage localization of these enzymes in the soluble fraction.

These data show that glucose-grown cells were low in the activities of aconitate hydratase, isocitrate lyase, fumarate hydratase, and succinate dehydrogenase.

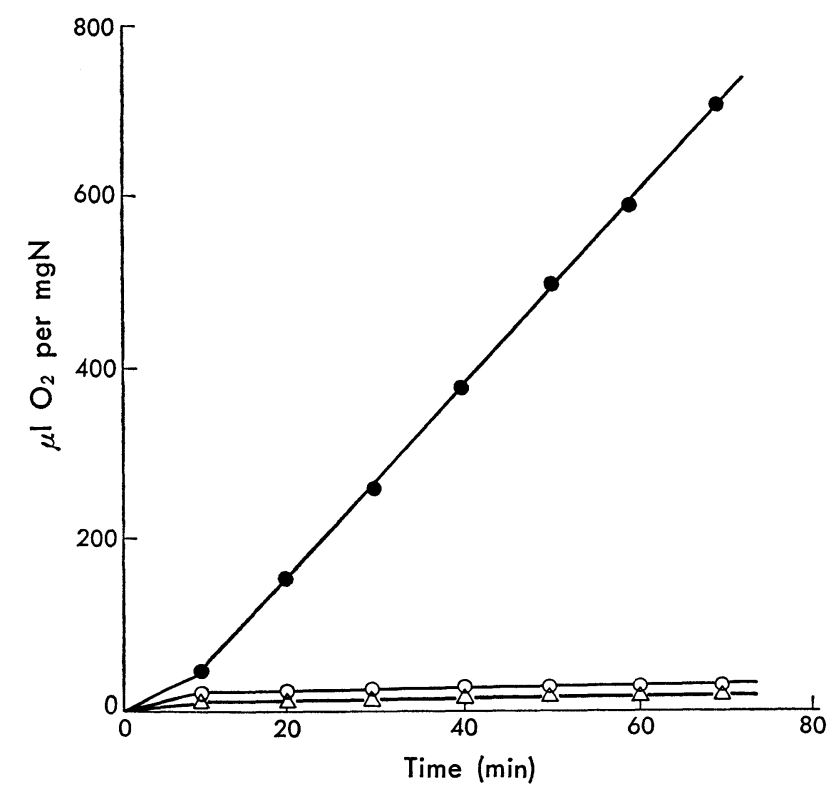

Fig. 1. Acetate oxidation by intact cells and cell fractions. $\bullet$ intact cells, $\bigcirc$ soluble fraction, $\Delta$ membrane fraction. 
Table 1. Enzyme activities in soluble and membrane fractions from cells grown aerobically or anaerobically, with or without glucose (means $\pm \operatorname{SEM}^{a}$ ).

\begin{tabular}{|c|c|c|c|c|c|c|}
\hline \multirow[t]{2}{*}{ Enzyme } & \multicolumn{3}{|c|}{$\begin{array}{l}\text { Cells grown } \\
\text { aerobically without glucose }\end{array}$} & \multicolumn{3}{|c|}{$\begin{array}{l}\text { Cells grown } \\
\text { aerobically with glucose }\end{array}$} \\
\hline & Soluble & & Membrane & Soluble & & Membrane \\
\hline Aconitate hydratase & $0.386 \pm 0.092$ & $6^{b}$ & $0.043 \pm 0.009$ & $0.047 \pm 0.009$ & 8 & $0.003 \pm 0.002$ \\
\hline Isocitrate lyase & $0.256 \pm 0.041$ & 6 & $0.051 \pm 0.013$ & $0.006 \pm 0.001$ & 8 & $0.002 \pm 0.001$ \\
\hline $\begin{array}{l}\text { Isocitrate } \\
\text { dehydrogenase }\end{array}$ & $2.630 \pm 0.100$ & 6 & $0.146 \pm 0.017$ & $1.205 \pm 0.275$ & 8 & $0.181 \pm 0.044$ \\
\hline Fumarate hydratase & $0.274 \pm 0.017$ & 7 & $0.019 \pm 0.003$ & $0.037 \pm 0.009$ & 8 & $0.003 \pm 0.001$ \\
\hline $\begin{array}{l}\text { NAD-Malate } \\
\text { dehydrogenase }\end{array}$ & $3.135 \pm 0.250$ & 6 & $0.550 \pm 0.096$ & $0.376 \pm 0.060$ & 8 & $0.327 \pm 0.051$ \\
\hline $\begin{array}{l}\text { NADP-Malate } \\
\text { dehydrogenase }\end{array}$ & $0.363 \pm 0.043$ & 6 & $0.044 \pm 0.008$ & $0.019 \pm 0.004$ & 8 & $0.002 \pm 0.001$ \\
\hline $\begin{array}{l}\text { Succinate } \\
\text { dehydrogenase }\end{array}$ & $0.144 \pm 0.014$ & 8 & $0.483 \pm 0.057$ & $0.035 \pm 0.007$ & 8 & $0.033 \pm 0.007$ \\
\hline $\begin{array}{l}\text { Formate } \\
\text { dehydrogenase }\end{array}$ & $0.425 \pm 0.050$ & 6 & $4.230 \pm 0.545$ & $0.262 \pm 0.049$ & 8 & $3.495 \pm 0.400$ \\
\hline NADH oxidase & $0.178 \pm 0.035$ & 8 & $0.576 \pm 0.037$ & $0.177 \pm 0.028$ & 8 & $0.389 \pm 0.047$ \\
\hline NADPH oxidase & $0.018 \pm 0.002$ & 6 & $0.009 \pm 0.001$ & $0.025 \pm 0.005$ & 8 & $0.004 \pm 0.001$ \\
\hline $\begin{array}{l}\text { Menadione } \\
\text { reductase }\end{array}$ & $3.250 \pm 0.530$ & 6 & $0.597 \pm 0.066$ & $2.135 \pm 0.220$ & 5 & $0.628 \pm 0.020$ \\
\hline Cytochrome $b_{1}$ & $0.176 \pm 0.008$ & 5 & $0.666 \pm 0.030$ & $0.090 \pm 0.008$ & 4 & $0.442 \pm 0.064$ \\
\hline \multirow[t]{2}{*}{ Enzyme } & \multicolumn{3}{|c|}{$\begin{array}{l}\text { Cell grown } \\
\text { anaerobically without glucose }\end{array}$} & \multicolumn{3}{|c|}{$\begin{array}{l}\text { Cell grown } \\
\text { anaerobically with glucose }\end{array}$} \\
\hline & Soluble & & Membrane & Soluble & & Membrane \\
\hline Aconitate hydratase & $0.129 \pm 0.016$ & 5 & $0.003 \pm 0.001$ & $0.029 \pm 0.005$ & 6 & $0.001 \pm 0.001$ \\
\hline Isocitrate lyase & $0.012 \pm 0.001$ & 5 & $0.0004 \pm 0.0001$ & $0.005 \pm 0.001$ & 6 & $0.001 \pm 0.000$ \\
\hline $\begin{array}{l}\text { Isocitrate } \\
\text { dehydrogenase }\end{array}$ & $0.661 \pm 0.088$ & 5 & $0.011 \pm 0.007$ & $0.245 \pm 0.013$ & 6 & $0.003 \pm 0.000$ \\
\hline Fumarate hydratase & $0.113 \pm 0.013$ & 5 & $0.012 \pm 0.002$ & $0.042 \pm 0.008$ & 6 & $0.004 \pm 0.003$ \\
\hline $\begin{array}{l}\text { NAD-Malate } \\
\text { dehydrogenase }\end{array}$ & $2.335 \pm 0.070$ & 5 & $0.330 \pm 0.042$ & $1.890 \pm 0.230$ & 6 & $0.116 \pm 0.006$ \\
\hline $\begin{array}{l}\text { NADP-Malate } \\
\text { dehydrogenase }\end{array}$ & $0.079 \pm 0.006$ & 5 & $0.008 \pm 0.001$ & $0.050 \pm 0.008$ & 6 & $0.001 \pm 0.000$ \\
\hline $\begin{array}{l}\text { Succinate } \\
\text { dehydrogenase }\end{array}$ & $0.101 \pm 0.008$ & 5 & $0.271 \pm 0.029$ & $0.045 \pm 0.003$ & 10 & $0.041 \pm 0.007$ \\
\hline $\begin{array}{l}\text { Formate } \\
\text { dehydrogenase }\end{array}$ & $0.243 \pm 0.027$ & 5 & $2.585 \pm 0.165$ & $0.079 \pm 0.013$ & 10 & $0.254 \pm 0.043$ \\
\hline NADH oxidase & $0.122 \pm 0.004$ & 5 & $0.242 \pm 0.011$ & $0.114 \pm 0.011$ & 10 & $0.072 \pm 0.011$ \\
\hline $\begin{array}{l}\text { NADPH oxidase } \\
\text { Menadione }\end{array}$ & $0.031 \pm 0.005$ & 5 & $0.005 \pm 0.000$ & $0.018 \pm 0.002$ & 6 & $0.004 \pm 0.000$ \\
\hline reductase & & & & $3.335 \pm 0.280$ & 6 & $0.105 \pm 0.014$ \\
\hline Cytochrome $b_{1}$ & $0.097 \pm 0.003$ & 4 & $0.208 \pm 0.017$ & $0.053 \pm 0.006$ & 4 & $0.088 \pm 0.011$ \\
\hline
\end{tabular}

Enzyme activities are expressed as $\mu \mathrm{mol}$ of substrate consumed or product formed per min per soluble or membrane fraction from $100 \mathrm{mg}$ wet cells. Cytochrome contents are expressed as absorbancy at $428 \mathrm{~nm}$ of the solution containing the fractions from $100 \mathrm{mg}$ cells per $\mathrm{ml}$.

$a \quad \mathrm{SEM}=$ standard error of the mean. $\quad b \quad$ Figures are the number of experiments. 
Table 2. Effect of growth conditions on the total activity and localization of respiratory enzymes.

\begin{tabular}{|c|c|c|c|c|c|c|c|c|}
\hline \multirow[t]{2}{*}{ Enzyme } & \multicolumn{2}{|c|}{$\begin{array}{c}\text { Aerobic } \\
\text { without glucose }\end{array}$} & \multicolumn{2}{|c|}{$\begin{array}{c}\text { Aerobic } \\
\text { with glucose }\end{array}$} & \multicolumn{2}{|c|}{$\begin{array}{c}\text { Anaerobic } \\
\text { without glucose }\end{array}$} & \multicolumn{2}{|c|}{$\begin{array}{c}\text { Anaerobic } \\
\text { with glucose }\end{array}$} \\
\hline & Activity & Sol. $(\%)$ & Activity & Sol. $(\%)$ & Activity & Sol. (\%) & Activity & Sol. $(\%)$ \\
\hline Aconitate & & & & & & & & \\
\hline hydratase & 0.429 & 90.0 & 0.050 & 94.0 & 0.132 & 97.8 & 0.030 & 96.7 \\
\hline Isocitrate lyase & 0.307 & 83.4 & 0.008 & 75.0 & 0.012 & 96.8 & 0.006 & 83.3 \\
\hline $\begin{array}{l}\text { Isocitrate } \\
\text { dehydrogenase }\end{array}$ & 2.780 & 94.7 & 1.390 & 87.0 & 0.672 & 98.4 & 0.248 & 98.8 \\
\hline $\begin{array}{l}\text { Fumarate } \\
\text { hydratase }\end{array}$ & 0.293 & 93.5 & 0.040 & 92.5 & 0.125 & 90.3 & 0.046 & 91.3 \\
\hline $\begin{array}{l}\text { NAD-Malate } \\
\text { dehydrogenase }\end{array}$ & 3.685 & 85.1 & 0.703 & 53.5 & 2.665 & 87.6 & 2.006 & 94.2 \\
\hline $\begin{array}{l}\text { NADP-Malate } \\
\text { dehydrogenase }\end{array}$ & 0.407 & 89.2 & 0.021 & 90.5 & 0.087 & 90.8 & 0.051 & 98.0 \\
\hline $\begin{array}{l}\text { Succinate } \\
\text { dehydrogenase }\end{array}$ & 0.627 & 23.0 & 0.069 & 50.7 & 0.372 & 27.2 & 0.086 & 52.3 \\
\hline $\begin{array}{l}\text { Formate } \\
\text { dehydrogenase }\end{array}$ & 4.655 & 9.1 & 3.755 & 7.0 & 2.830 & 8.6 & 0.333 & 23.7 \\
\hline NADH oxidase & 0.754 & 23.6 & 0.566 & 31.3 & 0.364 & 33.5 & 0.186 & 61.3 \\
\hline NADPH oxidase & 0.027 & 66.7 & 0.029 & 86.2 & 0.036 & 86.1 & 0.022 & 81.8 \\
\hline $\begin{array}{l}\text { Menadione } \\
\text { reductase }\end{array}$ & 3.845 & 84.5 & 2.760 & 77.3 & & & 3.440 & 96.9 \\
\hline Cytochrome $b_{1}$ & 0.842 & 20.9 & 0.532 & 16.9 & 0.305 & 31.8 & 0.141 & 37.6 \\
\hline
\end{tabular}

Total activity is the sum of the activities (mean values) in soluble fraction and membrane fraction that are listed in Table 1. Localization is expressed as percentage activity in soluble fraction (Sol. \%) compared to the total activity.

These results almost agree with those reported by previous workers (4-6). Glucose also repressed the level of malate dehydrogenases when cells were grown aerobically. The levels of formate dehydrogenase, NADH oxidase, NADPH oxidase, menadione reductase, and cytochrome $b_{1}$ were relatively insensitive to glucose.

The data in these tables also show that the absence of oxygen during growth decreased the levels of aconitate hydratase, isocitrate lyase, isocitrate dehydrogenase, fumarate hydratase, NADP-malate dehydrogenase, NADH-oxidase, and cytochrome $b_{1}$. Oxygen did not distinctly influence the levels of NAD-malate dehydrogenase, NADPH oxidase, and menadione reductase. These results almost coincide with the observations by GraY et al. (5) and by TAKAHASHI and HinO (6), but there are some differences. Both groups reported that the level of formate dehydrogenase was strongly repressed by anaerobiosis, but in their experiments only sugar-containing media were used for the cultivation of bacteria. The present result shows that the level of formate dehydrogenase was similar between aerobically and anaerobically grown cells when the cells were cultured in the absence of glucose; the synthesis of this enzyme was repressed only when the cells were grown anaerobically with glucose. Similar synergetic repressive effect between glucose and anaerobiosis could be seen on the level of NADH oxidase. 
In yeast cells, either growth on glucose or growth under anaerobic condition represses the development of mitochondrial structure and leads to negligible synthesis of mitochondrial respiratory enzymes. Although glucose and anaerobiosis also repress the development of respiratory enzymes in E. coli, either condition alone does not lead to the decrease of the whole Krebs cycle and electron transport enzymes; glucose is rather ineffective in the repression of electron transport enzymes (except succinate dehydrogenase), while anaerobiosis is rather ineffective in the repression of enzymes in the metabolism of dicarboxylic acids.

The localization of various respiratory enzymes among cell fractions of $E$. coli has been reported $(5,7)$. The general pattern of the distribution of these enzymes between soluble and membrane fractions, as shown in Tables 1 and 2, is consistent with these previous observations. Aconitate hydratase, isocitrate lyase, isocitrate dehydrogenase, fumarate hydratase, and malate dehydrogenases are for the most part soluble, while bulk of succinate dehydrogenase, formate dehydrogenase, NADH oxidase, and cytochrome $b_{1}$ are localized in the membrane fraction. As for menadione reductase, the localization of this enzyme was originally reported to be membraneous (12), but later BRAGG and Hou (13) showed that the enzyme is distributed both in soluble and membrane fractions. They also showed that membrane-bound reductase was solubilized by osmotic shock of the cells or by the treatment of membranes with EDTA. Since our procedures for obtaining membrane preparations involve EDTA treatment and osmotic shock, most of menadione reductase must have been solubilized as shown in Table 1 .

It is not possible from the present study to differentiate the two environmental factors, glucose and anaerobiosis, in terms of structural localization of the susceptible enzymes, since either condition affects some soluble and some membranebound enzymes. However, the present result shows that, when the synthesis of enzymes that are generally membraneous was repressed by glucose and anaerobiosis, the proportion of the enzyme activity in soluble fraction increased considerably. For example, when cells were grown aerobically without glucose, the percentage of the activity in the soluble fraction of succinate dehydrogenase, formate dehydrogenase, NADH oxidase, and cytochrome $b_{1}$ was about 23, 9, 24, and 21 , respectively, but, when the cells were grown anaerobically with glucose, the corresponding percentage was about 52, 24, 61, and 38, respectively (Table 2). These results may be due to the following two possibilities: (1) There are soluble and membrane-bound isozymes in these enzymes and the latter are more sensitive to the repression, and (2) there is one kind of enzymes and, under the condition of synthesis of membraneous enzymes being repressed, some modifications in membrane structure occur so that membrane-bound enzymes tend to become solubilized. To test the second possibility, comparison of the chemical composition of membrane fractions derived from various culture conditions is under study in our laboratory. 


\section{REFERENCES}

1) P. P. Slonimski, Proc. 3rd Int. Congr. Biochem., 242 (1956).

2) E. S. Polakis, W. Bartley, and G. A. Meek, Biochem. J., 90, 369 (1964).

3) A. W. Linnane, E. Vitols, and P. G. Nowland, J. Cell Biol., 13, 345 (1962).

4) Y. S. Halpern, A. Even-Shoshan, and M. Artman, Biochim. Biophys. Acta, 93, 228 (1964).

5) C. T. Gray, J. W. T. Wimpenny, and M. R. Mossman, Biochim. Biophys. Acta, 117, 33 (1966).

6) Y. TAkahashi and S. Hino, J. Gen. Appl. Microbiol., 14, 429 (1968).

7) R. W. Hendler, A. H. Burgess, and R. Scharff, J. Cell Biol., 42, 715 (1969).

8) S. Hino and M. Maeda, J. Gen. Appl. Microbiol., 12, 247 (1966).

9) Y. Nagata, S. Mizuno, and B. Maruo, J. Biochem. (Tokyo), 59, 404 (1966).

10) R. D. Sanadi, R. L. Pharo, and L. A. Sordahl, Methods Enzymol., 10, 297 (1967).

11) Y. Takahashi and S. Hino, J. Gen. Appl. Microbiol., 14, 183 (1968).

12) E. R. Kashket and A. F. Brodie, Biochim. Biophys. Acta, 78, 52 (1963).

13) P. D. Bragg and C. Hou, Can. J. Biochem., 45, 1107 (1967). 